\title{
CHAPTER C: REGIONAL CORRELATION OF METAMORPHIC ROCKS IN THE LADUE RIVER-MOUNT FAIRPLAY MAP AREA USING TRACE-ELEMENT GEOCHEMISTRY OF METAMAFIC ROCKS
}

Travis J. Naibert ${ }^{1}$ and Alicja Wypych ${ }^{1}$

\section{INTRODUCTION}

The allochthonous Yukon-Tanana Terrane (YTT) and parautochthonous North America (pNA) share Late Devonian and older geologic histories and have similar pre-Mississippian metasedimentary units (Colpron and others, 2006). The YTT is generally interpreted as a continental fragment that was rifted from the North American margin in the Devonian to Mississippian and re-accreted to the continent in the Permian to Jurassic (Colpron and others, 2006). Similar lithologies, internal deformation within the YTT before and during collision with the continental margin, and deformation during subsequent mid-Cretaceous extension, make it difficult to correlate units regionally and to differentiate allochthonous and parautochthonous rocks.

During initial geologic mapping of the Tanacross Quadrangle, Foster (1970) identified an area of quartz-mica schist that she tentatively correlated to the Klondike Schist (Cockfield, 1921) in the adjacent Yukon. Dusel-Bacon and others (2006) obtained a Devonian $\mathrm{U}-\mathrm{Pb}$ zircon age for one sample of this unit, precluding a simple correlation of these rocks to the Permian Klondike assemblage; they named the area the "Ladue River unit" and left regional correlations to future study. U.S. Geological Survey (USGS) geologists recently obtained new U-Pb (Jones and O'Sullivan, 2020) and ${ }^{40} \mathrm{Ar} /{ }^{39} \mathrm{Ar}$ (Jones and Benowitz, 2020) geochronology data, enabling the Ladue River area to be subdivided into areas of Devonian-Mississippian and Permian magmatic ages (Jones and others, 2017). Our geochronology (Wildland and others, 2021) and mapping (Twelker and others, 2021) supports this basic subdivision.
Significant questions of regional correlation remain despite the new age control, including whether the Devonian-Mississippian Ladue River unit rocks are affiliated with the Snowcap assemblage or the Fortymile River assemblage, and whether the Permian metaigneous rocks are truly correlative with the Klondike assemblage. All of the metamorphic assemblages in the Ladue RiverMount Fairplay map area include metamorphosed mafic rocks (Newberry and Twelker, 2021; Twelker and others, 2021) and the trace element variations of metamafic rocks have been used to characterize metamorphic terranes in the region (for example, Dusel-Bacon and Cooper, 1999; Dusel-Bacon and others, 2006). In this chapter we compare trace-element geochemistry of the metamafic units to published trace-element data from eastern Alaska and Yukon to aid in correlation of regional geologic units. Mafic traceelement geochemistry can also be used to interpret tectonic environment of magmatism during protolith formation (for example, Meschede, 1986; Pearce, 2008). This chapter draws on wholerock geochemical analyses of metamafic rocks from the DGGS Eastern Tanacross project. A supplemental spreadsheet that relates map units to samples from the geochemical report used for this interpretation can be downloaded from https:// doi.org/10.14509/30739. See Wypych and others (2019; https://dggs.alaska.gov/pubs/id/30267) for full documentation of the sample collection, preparation, and analytical methods.

\section{Parautochthonous North America}

Units of pNA in the map area include the Lake George assemblage, the Divide Mountain augen gneiss, and the Jarvis belt. The Lake George assemblage

${ }^{1}$ Alaska Division of Geological \& Geophysical Surveys, 3354 College Rd., Fairbanks, Alaska 99709-3707 
and Divide Mountain augen gneiss are correlated with the adjacent Northeast Tanacross map area of Wypych and others (2021) based on field mapping. Lithologies of these units are consistent with the adjacent map area as well as with similar units described elsewhere in the Tanacross Quadrangle (Solie and others, 2019; Dusel-Bacon and others, 2002, 2006) and with the White River assemblage in western Yukon (Ryan and others, 2013). The Lake George assemblage and the Snowcap assemblage in Yukon have the same constituent lithologies, comparable amphibolite-facies metamorphic grades, and similar-age metaplutonic rocks as the above-mentioned units of pNA. Lake George assemblage rocks have Early Cretaceous ${ }^{40} \mathrm{Ar} /{ }^{39} \mathrm{Ar}$ cooling ages in eastern Alaska, whereas allochthonous amphibolite-facies units, including the Snowcap assemblage, have Triassic to Jurassic ${ }^{40} \mathrm{Ar} /{ }^{39} \mathrm{Ar}$ cooling ages (Dusel-Bacon and others, 2002; Naibert and others, 2020; Jones and Benowitz, 2020), which aided mapping in multiple locations.

Amphibolite samples from the Lake George assemblage in the Ladue River-Mount Fairplay map area and the adjacent Northeast Tanacross map area have alkali-basalt to basalt protoliths and their trace element geochemistry indicates tectonic environments ranging from volcanic arc basalts to within-plate basalts and mid-ocean-ridge basalts (MORB) (figs. 1A and E). The few published U-Pb zircon ages from Lake George amphibolites are all Late Devonian to Early Mississippian (ca. 351-365 Ma: Jones and O'Sullivan, 2020; Todd and others, 2019; and further west in the Big Delta Quadrangle, 369 Ma: Day and others, 2003; DuselBacon and others, 2004). Within-plate basalts and MORB basalts are consistent with rifting of the Laurentian margin, which is proposed during that time period by many workers (for example, Dusel-Bacon and Cooper, 1999; Dusel-Bacon and others, 2004; Colpron and others, 2006). Three episodes of Paleozoic mafic volcanism are reported in the correlative Selwyn Basin in Yukon (Mair and others, 2006) and the Lake George assemblage amphibolites may have originated during tectonic events not recorded in the available geochronology.
Correlation of the Lake George assemblage with the same unit in the Northeast Tanacross map area to the north is well supported by overlap of amphibolite trace-element geochemistry (fig. 1; Wypych and others, 2017; 2018). The Lake George samples in the Northeast Tanacross map area include a higher proportion of MORB basalts exhibiting less crustal contamination compared to those in the Ladue River-Mount Fairplay area, and the Northeast Tanacross area also includes more numerous interlayered amphibolites, which may be a result of differing proximity to eruptive centers during continental rifting. Some amphibolites from the Lake George assemblage collected from the northeastern Tanacross quadrangle from different sample localities than from those reported in Wypych and others $(2017 ; 2018)$, as well as some from the Big Delta and Healy quadrangles west and southwest of our study area, respectively, have within-plate (OIB) trace-element signatures (Dusel-Bacon and Cooper, 1999; Dusel-Bacon and others, 2004) indicative of rifting.

The Jarvis belt units in the southwest part of the map area are projected from contacts in the adjacent Alaska Highway corridor geologic map (Solie and others, 2019) and approximately correspond to the phyllite and schist unit Pa of Foster (1970). Wildland and others (2021) determined a ca. $367 \mathrm{Ma}$ U-Pb zircon age from a felsic metavolcanic sample, and Solie and others (2019) reported a $351.7 \pm 9.3 \mathrm{U}-\mathrm{Pb}$ zircon age from a similar sample. These ages and abundant interlayered quartz-rich metasediments support the correlation of units in the Ladue River-Mount Fairplay map area to the metavolcanic Jarvis belt units in the Tok River area (Sicard and others, 2017), the Delta mineral belt (Dashevsky and others, 2003), and to the White River assemblage of Ryan and others (2014). Greenstone (kgs) within the Jarvis belt units in the map area is lithologically similar to Triassic metagabbros in the Alaska Highway corridor (Solie and others, 2019), the Tok River map area (Sicard and others, 2017), and the Delta mineral belt (Dashevsky and others, 2003). Trace-element geochemistry was not 


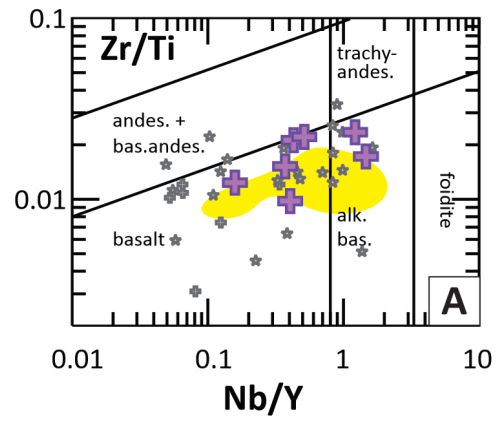

54 Lake George Assemblage amphibolite (E Tanacross map area, Wypych and others 2019)

* Lake George Assemblage amphibolite (NE Tanacross map area, Wypych and others 2017,2018)

Lake George Assemblage amphibolite (Dusel-Bacon and Cooper, 1999

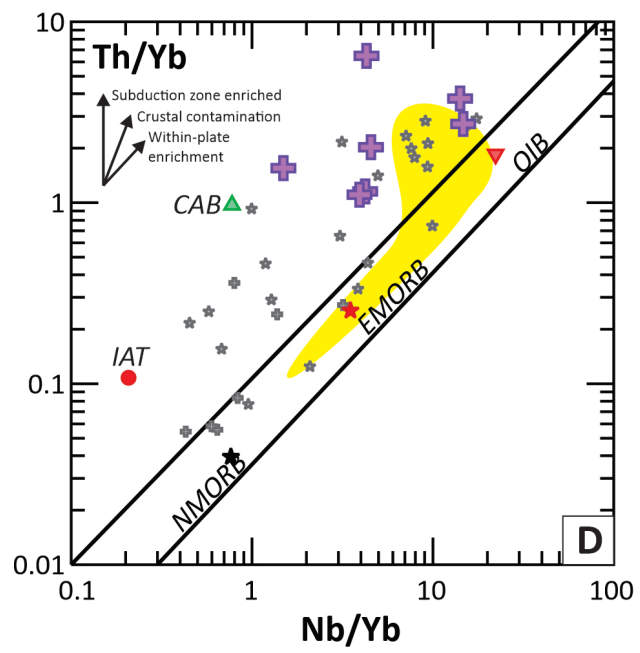

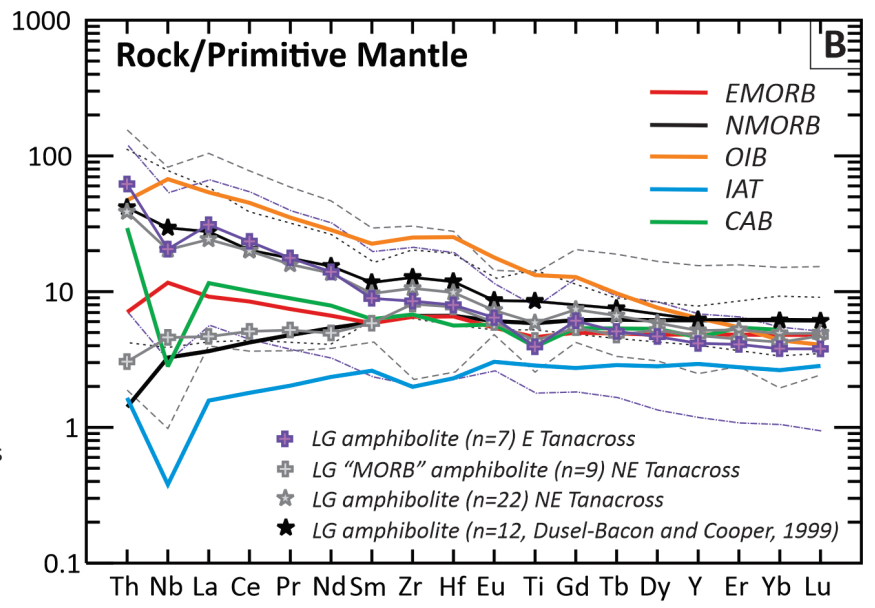

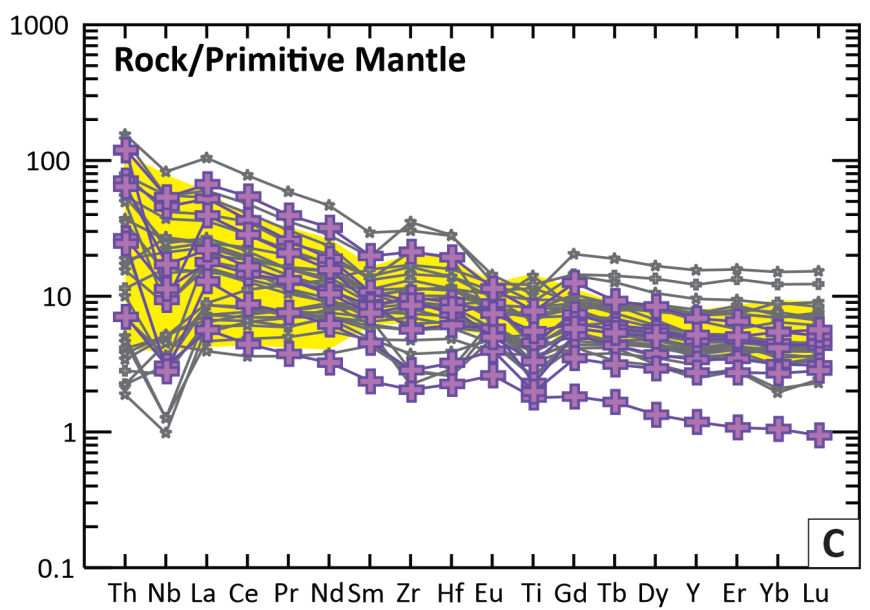

\section{Nbx2}

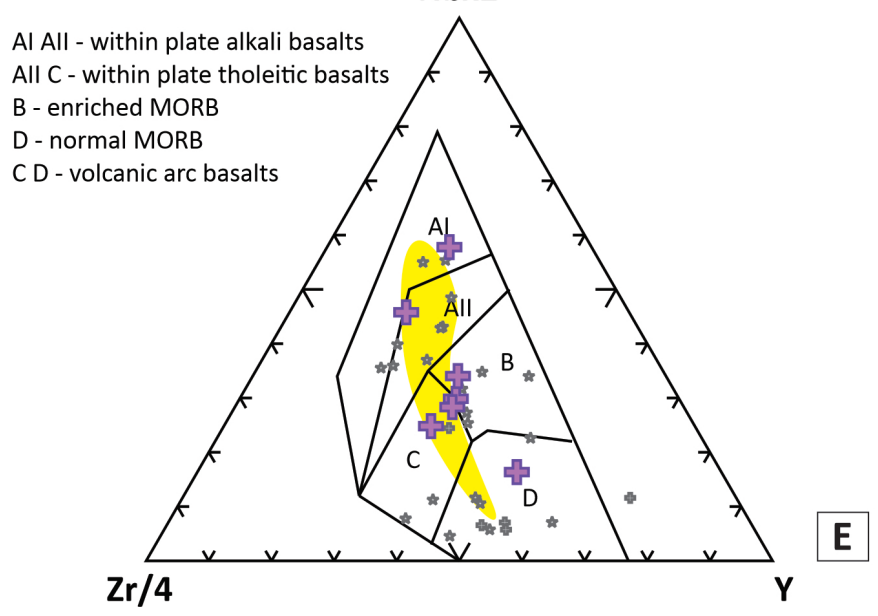

Figure 1. Trace-element geochemistry of amphibolites collected in the Lake George assemblage within the Ladue River-Mount Fairplay map area with comparison to Lake George assemblage amphibolites collected within the adjacent Northeast Tanacross map area (Wypych and others, 2017; 2018) and amphibolite samples in Dusel-Bacon and Cooper (1999). A. Magma-series discrimination diagram of Winchester and Floyd (1977). B. Primitive mantle-normalized spider diagram of Sun and McDonough (1989) with average of sample values (symbols) and sample minimums and maximums (dashed lines) compared to expected patterns from common tectonic environments. C. Primitive mantle-normalized spider diagram of Sun and McDonough (1989) with all sample values (symbols). D. Th/Yb vs. Nb/Yb basalt classification diagram of Pearce (2008). E. Nb-Zr-Y ternary diagram for basalt tectonic discrimination of Meschede (1986). 
measured from these metamafic units, but they are likely correlated with the Triassic Snag Creek suite within the White River assemblage in western Yukon based on lithology and their association with felsic metavolcanic units (Ryan and others, 2013).

\section{Allochthonous Terranes}

Allochthonous units in the Ladue RiverMount Fairplay map area include the Ladue River unit of Dusel-Bacon and others (2006), ultramafic slivers of the Seventymile Terrane, and Permian schistose units that we correlate to the Klondike Schist in Yukon. The Ladue River unit includes siliciclastic metasedimentary schist and paragneiss and interlayered metaplutonic rocks. The unit experienced amphibolite-facies metamorphism and large parts of the area have retrograde greenschist-facies mineralogy (Newberry and Twelker, 2021). Zircon U-Pb ages of metaplutonic rocks within the Ladue River unit are Late Devonian to Early Mississippian(Jones and O'Sullivan, 2020; Wildland and others, 2021) and overlap in age with metaigneous rocks of the Late Devonian Grass Lakes and the Early Mississippian Simpson Range intrusive suites within the Snowcap and Finlayson assemblages in Yukon (Yukon Geological Survey, 2020), and with both the Divide Mountain orthogneiss unit (named in this publication) in the Lake George assemblage and the older group of ages in the Fortymile River assemblage (DuselBacon and others, 2006).

Volumetrically minor amphibolite units are concordant with foliation and are interpreted as metamorphosed sills, though it is also possible that they could have mafic volcanic protoliths. One amphibolite from the map area yielded a zircon $\mathrm{U}-\mathrm{Pb}$ age of $361.8 \pm 1.6 \mathrm{Ma}$, suggesting the amphibolites are the same age as the more felsic Mississippian to Devonian metaplutonic rocks (ca. 363 Ma, Dusel-Bacon and others, 2006; ca. 371-361 Ma, Wildland and others, 2021). Trace-element geochemistry of amphibolites suggest basaltic to basaltic andesite protoliths from a volcanic arc or from within-plate tectonic environments (fig. 2).
The Ladue River unit amphibolite geochemistry overlaps the trace-element geochemistry of the Fortymile River assemblage amphibolites in the adjacent Northeast Tanacross map area and partially overlaps amphibolite trace-element geochemistry in the Snowcap (Piercey and Colpron, 2009) and Finlayson assemblages (Piercey and others, 2002) in Yukon (fig. 2).

Correlation of the Ladue River unit with the Snowcap assemblage is supported by the lack of marble layers and relative paucity of amphibolite layers in the Ladue River area. Within-plate trace element signatures from some amphibolites may reflect a continental rift setting akin to the Snowcap and Lake George assemblages. However, as clearly shown in figure $2 \mathrm{D}$, the volcanic-arc trace-element setting of the Ladue River amphibolites are similar to that for Fortymile River assemblage samples from the Northeast Tanacross map area, suggesting a likely correlation between these two units. Felsic porphyroclastic orthogneiss (MDpo) within the Ladue River unit is interpreted as metamorphosed volcanic or shallow subvolcanic rocks, which is likely further evidence of Early Mississippian Fortymile River/Finlayson arc volcanism. Orthogneiss bodies in the Ladue River unit have more granitic compositions compared to the granodiorite and tonalite compositions of orthogneisses in the Fortymile River assemblage in the Northeast Tanacross map area and in southeast Eagle Quadrangle (Werdon and others, 2001; Szumigala and others, 2002). Since deposition of the Snowcap assemblage sedimentary and volcanic layers is interpreted to transition into Finlayson deposition in some locations in Yukon (Colpron and others, 2006; Ryan and others, 2014), it is possible that the Ladue River unit also records a similar transition from rift-related siliciclastic sedimentation to the early stages of Finlayson arc volcanism. This interpretation would account for similarities to both the Snowcap and Fortymile River/Finlayson assemblages. Additionally, the Ladue River unit may represent a complex, structurally interleaved boundary between the Snowcap and Fortymile 


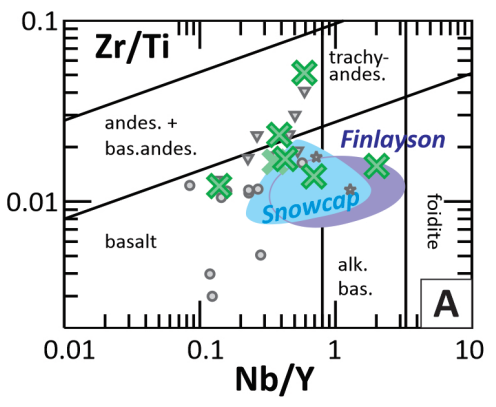

× Fortymile River Assemblage amphibolite (E Tanacross, Wypych and others 2019)

$\circ \nabla$ * Fortymile River Assemblage amphibolite (NE Tanacross map area, Wypych and others 2017, 2018) Snowcap assemblage (Piercey and Colpron, 2009)

Finlayson Lake region mafic rocks (Piercey and others, 2002)

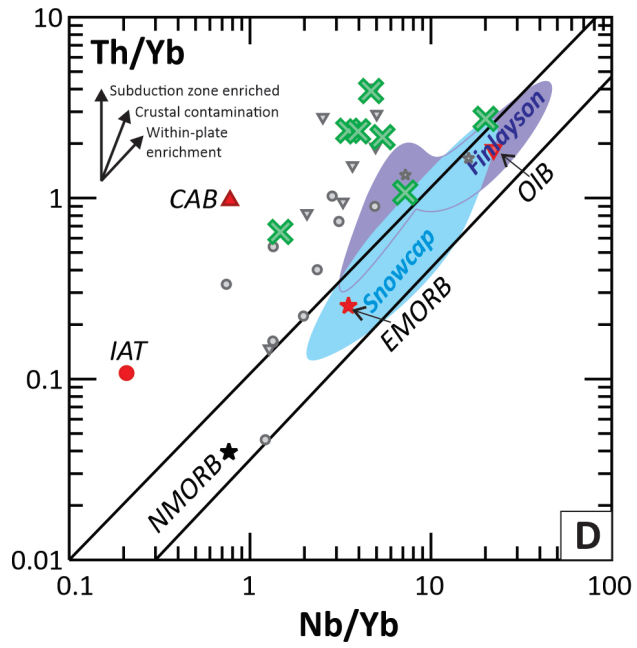

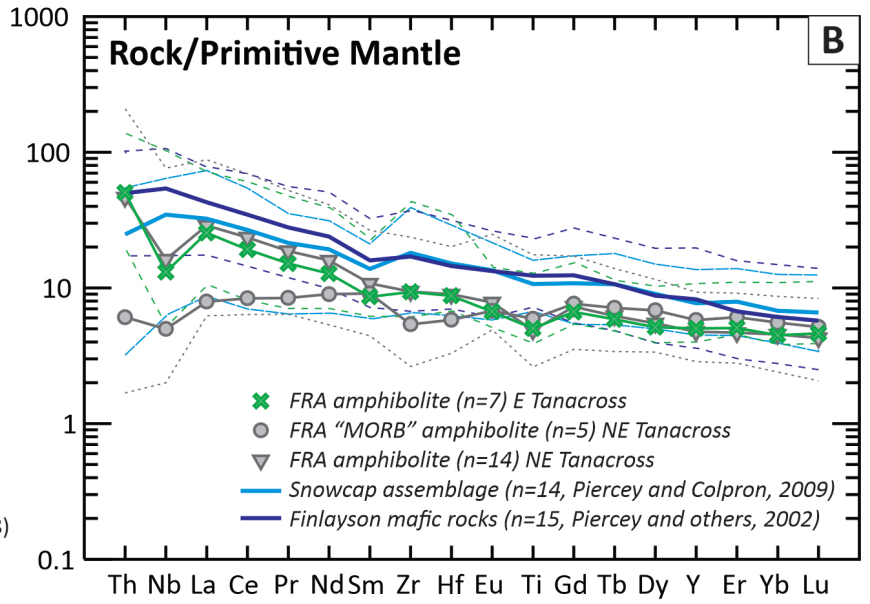

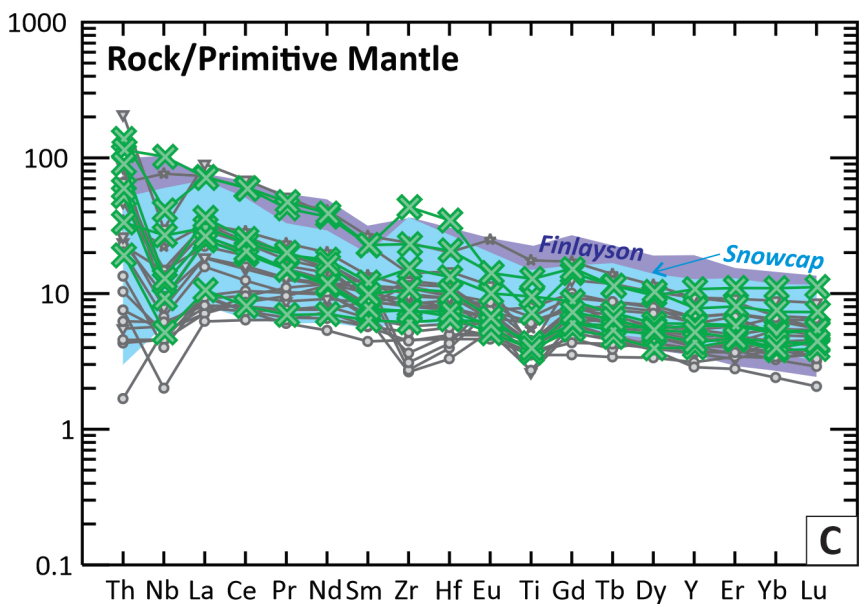

\section{Nbx2}

Al All - within plate alkali basalts All C - within plate tholeitic basalts $B$ - enriched MORB D - normal MORB C D - volcanic arc basalts

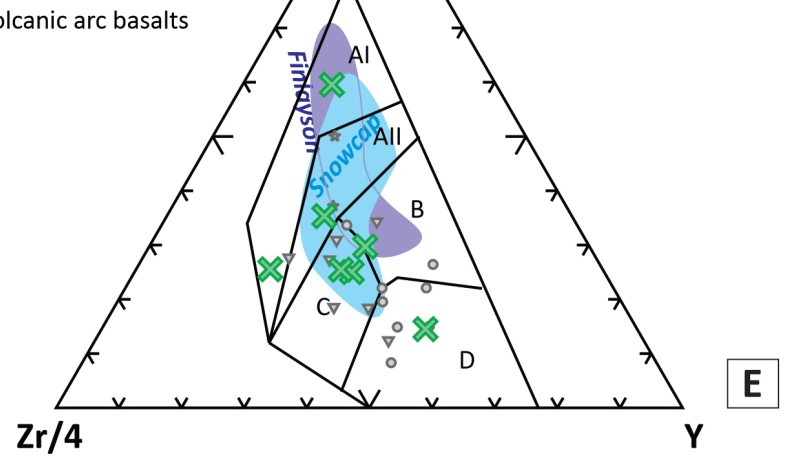

Figure 2. Trace element geochemistry of amphibolites collected in the Ladue River Unit within the Ladue River-Mount Fairplay map area with comparison to metamafic rocks of the Fortymile River assemblage in the Northeast Tanacross map area (Wypych and others, 2017; 2018) and the Finlayson and Snowcap assemblages in Yukon (Piercey and others, 2002; Piercey and Colpron, 2009). A. Magma series discrimination diagram of Winchester and Floyd (1977). B. Primitive mantle-normalized spider diagram of Sun and McDonough (1989) with average of sample values (symbols) and sample minimums and maximums (dashed lines). C. Primitive mantle-normalized spider diagram of Sun and McDonough (1989) with all sample values (symbols). D. Th/Yb vs. Nb/Yb basalt classification diagram of Pearce (2008). E. Nb-Zr-Y ternary diagram for basalt tectonic discrimination of Meschede (1986). 
River assemblages. If parts of the Ladue River area correlate to both the Snowcap and Fortymile River/ Finlayson assemblages, delineation of these internal boundaries is not possible with current data due to poor exposure.

The Permian Klondike assemblage in the Ladue River-Mount Fairplay map area includes quartz schist, white mica schist, and chlorite schist interpreted as metasedimentary rocks with minor felsic metavolcanic rocks. Interlayered greenstones and greenschists are interpreted as metamorphosed mafic volcanic rocks, although primary igneous textures are either completely overprinted by metamorphism or unrecognized due to poor exposure. Lack of outcropping contact relationships makes discrimination of basalt flows from sills impossible. These mafic metavolcanic layers are more common in our map area than they are in the dominantly felsic metavolcanic Klondike schist mapped in adjacent areas of Yukon (Beranek and Mortenson, 2011; Ryan and others, 2013). Trace-element geochemistry of the Permian metamafic rocks suggest volcanic arc basalt protoliths (fig. 3). The trace element patterns broadly overlap published data from mafic rocks of the Klondike assemblage (Milidragovic and others, 2016) and also overlaps data from mafic rocks of the Seventymile terrane (Erin Todd, U.S. Geological Survey, personal commun., 2018; Dusel-Bacon and others, 2006). The trace elements are less well matched to backarc basin basalt flows and shallow mafic intrusions in the Lower Permian Campbell Range formation of the Slide Mountain assemblage (Piercey and others, 2012), a correlative of the Seventymile terrane in the Finlayson Lake area of southeast Yukon. Zircon $\mathrm{U}-\mathrm{Pb}$ ages in the Klondike assemblage units in the map area range from 252 to $265 \mathrm{Ma}$ (Jones and O'Sullivan, 2020; Wildland and others, 2021) and, overlap with the more felsic Klondike assemblage units mapped in Yukon (Beranek and Mortenson, 2011). Additionally, the mapped greenstones do not appear to be tectonic slivers along fault zones and do not include interbedded chert as is common in the Seventymile terrane.

\section{CONCLUSIONS}

Regional correlations among the allochthonous units are complex, owing to the multiple generations of magmatism in the YTT and their protracted Paleozoic to Mesozoic deformational history. In the Eastern Tanacross map area, amphibolites and mafic-phase orthogneisses in the Ladue River unit, originally defined by Dusel-Bacon and others (2006), have trace-element geochemistry that is consistent with both volcanic-arc and back-arc magmatism. The trace-element characteristics overlap those of the Fortymile River assemblage in the northeast Tanacross Quadrangle and the correlative Finlayson assemblage in Yukon. Amphibolite trace element signatures from the Ladue River unit also partially overlap the Snowcap assemblage in Yukon and it is possible that correlatives of both the Fortymile River/Finlayson and the Snowcap assemblages are present in the Ladue River unit, either due to transitional deposition from Snowcap- to Finlayson-like protoliths during the Mississippian, or because of complex internal deformation that is unrecognized with the poor exposure in the map area.

The Permian Klondike assemblage mapped in the Ladue River-Mount Fairplay area likely correlates with the Klondike assemblage mapped in Yukon, though mafic volcanism in the Klondike arc is more widely preserved in Alaska and felsic metavolcanic rocks are more common in Yukon. Though Klondike metamafic trace elements also overlap the geochemistry of some greenstones in the Seventymile assemblage, field relationships do not suggest that these samples are from tectonic slices of seafloor as is interpreted for the Seventymile assemblage in Alaska.

Lake George assemblage map patterns, lithologies, U-Pb zircon ages, and metamafic trace-element geochemistry in the Ladue River-Mount Fairplay map area are compatible with the parautochthonous Lake George assemblage as defined elsewhere in eastern Alaska. Interlayered finergrained orthogneiss and amphibolite is character- 


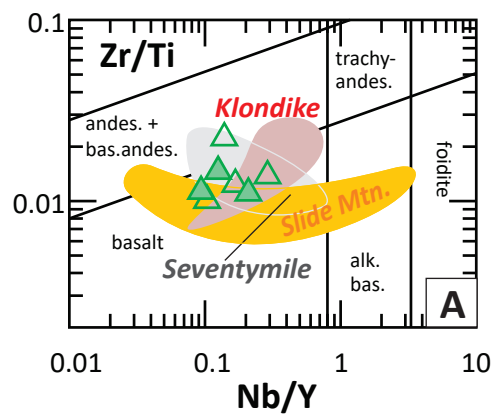

$\triangle \triangle$ Metabasite - E Tanacross (Wypych and others, 2019) Seventymile (Todd (USGS), written commun., 2018) Slide Mountain - Campbell Range Formation (Piercey and others, 2012)

Klondike mafic rocks (Milidragovic and others, 2016)
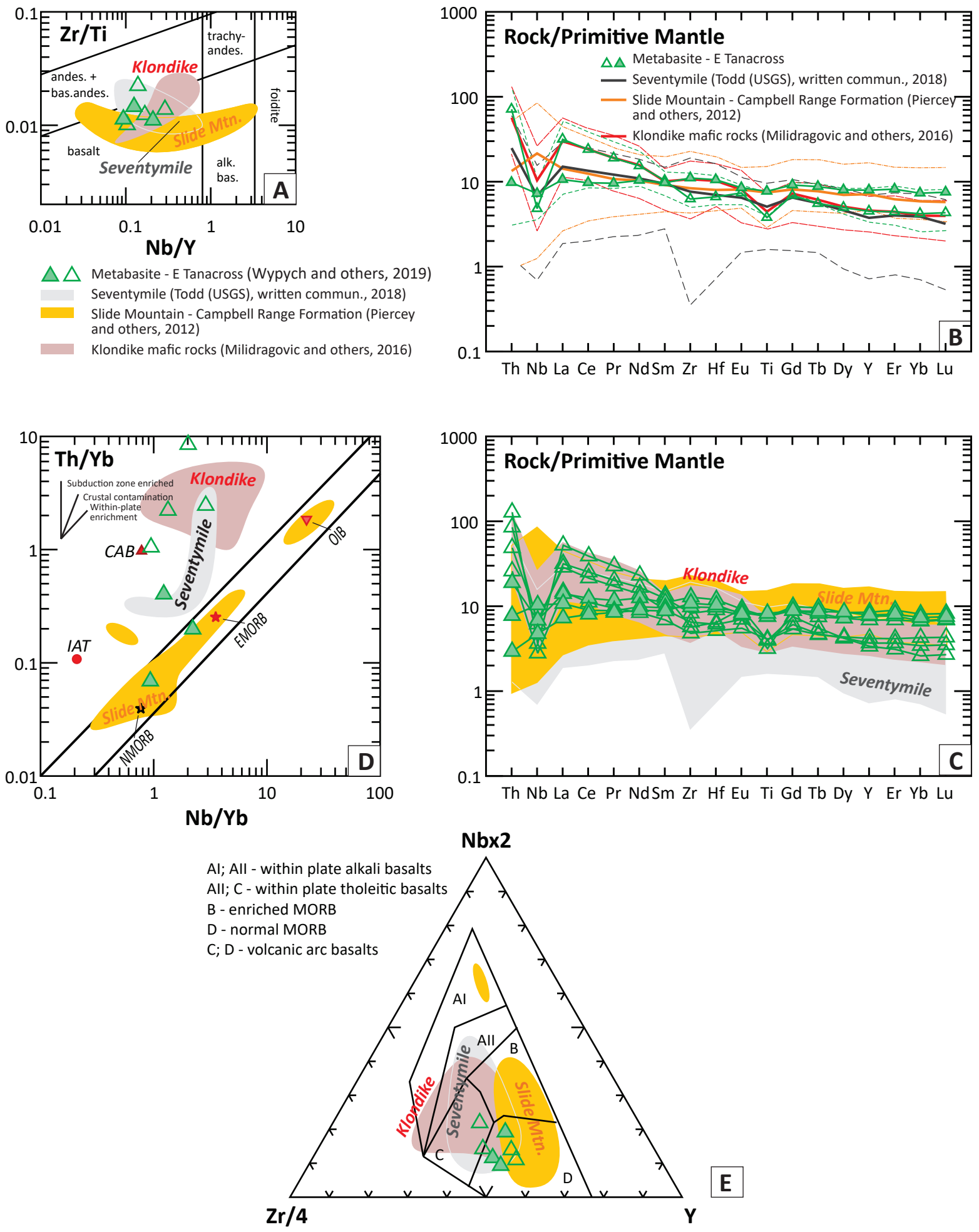

Figure 3. Trace element geochemistry of metamafic units collected in the Klondike assemblage within the Ladue River-Mount Fairplay map area with comparison to metamafic rocks of the Klondike and Slide Mountain assemblages in Yukon (Milidragovic and others, 2016; Piercey and others, 2012) and the Seventymile assemblage of eastern Alaska (Todd [USGS], written commun., 2018). A. Magma series discrimination diagram of Winchester and Floyd (1977). B. Primitive mantle-normalized spider diagram of Sun and McDonough (1989) with average of sample values (symbols) and sample minimums and maximums (dashed lines). C. Primitive mantle-normalized spider diagram of Sun and McDonough (1989) with all sample values (symbols). D. Th/Yb vs. Nb/Yb basalt classification diagram of Pearce (2008). E. Nb-Zr-Y ternary diagram for basalt tectonic discrimination of Meschede (1986). 
istic of the Lake George assemblage and is likely related to continental rifting, based on the trace-element geochemistry. The Jarvis belt in the eastern Alaska Range and in the Ladue River-Mount Fairplay map area likely correlates with the White River assemblage in western Yukon.

\section{ACKNOWLEDGMENTS}

We thank Cynthia Dusel-Bacon and Doug C. Kreiner for helpful reviews of this report. This project was jointly funded by the State of Alaska and the U.S. Geological Survey's Earth Mapping Resources Initiative (Earth MRI) through cooperative agreement G19AC00262. The views and conclusions contained in this document are those of the authors and should not be interpreted as representing the opinions or policies of the U.S. Geological Survey. Mention of trade names or commercial products does not constitute their endorsement by the U.S. Geological Survey.

\section{REFERENCES}

Beranek, L.P., and Mortensen, J.K., 2011, The timing of provenance record of the Late Permian Klondike orogeny in northwestern Canada and arc-continent collision along western North America: Tectonics, v. 30, 23 p. https://doi. org/10.1029/2010TC002849

Cockfield, W.E., 1921, Sixtymile and Ladue Rivers area, Yukon: Canada Geological Survey Memoir 123, no. 105, 60 p.

Colpron, Maurice, Nelson, J.L., and Murphy, D.C., 2006, A tectonostratigraphic framework for the pericratonic terranes of the northern Canadian Cordillera: Paleozoic Evolution and Metallogeny of Pericratonic Terranes at the Ancient Pacific Margin of North America, Canadian and Alaskan Cordillera, in Colpron, Maurice and Nelson, J.L., eds., Geological Association of Canada Special Paper 45, p. 1-23.

Dashevsky, S.S., Schaefer, C.F., and Hunter, E.N., 2003, Bedrock geologic map of the Delta mineral belt, Tok mining district, Alaska: Alaska Division of Geological \& Geophysical Surveys Professional Report 122, 122 p., 2 sheets, scale 1:63,360. https://doi.org/10.14509/2923
Day, W.C., Aleinikoff, J.N., Roberts, Paul, Smith, Moira, Gamble, B.M., Henning, M.W., Gough, L.P., and Morath, L.C., 2003, Geologic map of the Big Delta B-2 Quadrangle, east-central Alaska: U.S. Geological Survey Geologic Investigations Series Map 2788, 1 sheet, scale 1:63,360.

Dusel-Bacon, Cynthia, and Cooper, K.M., 1999, Trace-element geochemistry of metabasaltic rocks from the Yukon-Tanana Upland and implications for the origin of tectonic assemblages in east-central Alaska: Canadian Journal of Earth Sciences, v. 36, no. 10, p. 1,671-1,695.

Dusel-Bacon, Cynthia, Hopkins, M.J., Mortensen, J.K., Dashevsky, S.S., Bressler, J.R., Day, W.C., 2006, Paleozoic tectonic and metallogenic evolution of the pericratonic rocks of east-central Alaska and adjacent Yukon Territory: Paleozoic Evolution and Metallogeny of Pericratonic Terranes at the Ancient Pacific Margin of North America, Canadian and Alaskan Cordillera, Colpron, in Maurice and Nelson, J.L., eds., Geological Association of Canada Special Paper 45, p. 25-74.

Dusel-Bacon, Cynthia, Lanphere, M.A., Sharp, W.D., Layer, P.W., and Hanson, V.L., 2002, Mesozoic thermal history and timing of structural events for the Yukon-Tanana Upland, east-central Alaska - ${ }^{40} \mathrm{Ar} /{ }^{39} \mathrm{Ar}$ data from metamorphic and plutonic rocks: Canadian Journal of Earth Sciences, v. 39, no. 6, p. 1,013-1,051.

Dusel-Bacon, Cynthia, Wooden, J.L., and Hopkins, M.J., 2004, U-Pb zircon and geochemical evidence for bimodal mid-Paleozoic magmatism and syngenetic base-metal mineralization in the Yukon-Tanana terrane, Alaska: Geological Society of America, Bulletin v. 116, no. 7-8, p. 989-1,015.

Foster, H.L., 1970, Reconnaissance Geologic Map of the Tanacross Quadrangle, Alaska: U.S. Geological Survey Miscellaneous Geologic Investigations Map 593, 1 sheet, scale 1:250,000.

Jones III, J.V., and Benowitz, J.A., 2020, ${ }^{40} \mathrm{Ar} /{ }^{39} \mathrm{Ar}$ isotopic data and ages for rocks from the $\mathrm{Yu}$ kon-Tanana upland of eastern Alaska and the northern Aleutian Range of south-central Alaska: U.S. Geological Survey data release. https:// doi.org/10.5066/P96762V3

Jones III, J.V., and O'Sullivan, Paul, 2020, U-Pb isotopic data and ages of zircon, titanite, and 
detrital zircon from rocks from the Yukon-Tanana Upland, Alaska: U.S. Geological Survey data release. https://doi.org/10.5066/P9WWV93S

Jones III, J.V., Todd, Erin, Caine, J.S., Holm-Denoma, C.S., Ryan, J.J., and Benowitz, J.A., 2017, Late Permian (ca. 267-257 Ma) magmatism, deformation, and metamorphism and lithotectonic associations of the Ladue River unit in east-central Alaska: Geological Society of America Abstracts with Programs, v. 49, no. 6. https://doi.org/10.1130/abs/2017AM-304170

Mair, J.L., Hart, C.J.R., Stephens, J.R., 2006, Deformation history of the northwestern Selwyn Basin, Yukon, Canada: Implications for orogen evolution and mid-Cretaceous magmatism: Geological Society of America Bulletin, v. 118, p. 304-323.

Meschede, Martin, 1986, A method of discriminating between different types of midocean ridge basalts and continental tholeiites with the $\mathrm{Nb}-\mathrm{Zr}-\mathrm{Y}$ diagram: Chemical Geology, v. 56, p, 207-218. https://doi.org/10.1016/00092541(86)90004-5

Milidragovic, Dejan, Ryan, J.J., Zagorevski, Alexandre, Piercey, S.J., 2016, Geochemistry of Permian rocks of the Yukon-Tanana terrane, western Yukon: GEMS 2 Cordillera project: Geological Survey of Canada Open File 8170, 21 p.

Naibert, T.J., Benowitz, J.A., Wypych, Alicja, Sicard, K.R., and Twelker, Evan, 2020, ${ }^{40} \mathrm{Ar} /{ }^{39} \mathrm{Ar}$ data from the Tanacross D-1 and parts of the D-2, C-1, and C-2 quadrangles, Alaska: Alaska Division of Geological \& Geophysical Surveys Raw Data File 2020-12, 35 p. https://doi. org/10.14509/30466

Newberry, R.J., and Twelker, Evan, 2021, Metamorphism of the Ladue River-Mount Fairplay area, in Twelker, Evan, ed., Geologic investigation of the Ladue River-Mount Fairplay area, eastern Alaska: Alaska Division of Geological \& Geophysical Surveys Report of Investigation 2021-5B. https://doi.org/10.14509/30736

Pearce, Julian, 2008, Geochemical fingerprinting of oceanic basalts with applications to ophiolite classification and the search for Archean oceanic crust: Lithosphere, v. 100, p. 14-48. https://doi. org/10.1016/j.lithos.2007.06.016

Piercey, S.J., and Colpron, Maurice, 2009, Composition and provenance of the Snowcap assemblage, basement to the Yukon-Tanana terrane, northern Cordillera: Implications for Cordilleran crustal growth: Geosphere, v. 5, p. 439-464. https://doi.org/10.1130/GES00505.1

Piercey, S.J., Mortensen, J.K., Murphy, D.C., Paradis, Suzanne, and Creaser, R.A., 2002, Geochemistry and tectonic significance of alkalic mafic magmatism in the Yukon-Tanana terrane, Finlayson Lake region, Yukon: Canadian Journal of Earth Science, v. 39, p. 1,729-1,744. https:// doi.org/10.1139/e02-090

Piercey, S.J., Murphy, D.C., Creaser, R.A., 2012, Lithosphere-asthenosphere mixing in a transform-dominated late Paleozoic backarc basin: Implications for northern Cordilleran crustal growth and assembly: Geosphere, v. 8, p. 716739. https://doi.org/10.1130/GES00757.1

Ryan, J.J., Zagorevsky, Alexandre, Roots, C.F., and Joyce, N.L., 2014, Paleozoic tectonostratigraphy of the northern Stevenson Ridge area, Yukon: Geological Survey of Canada, Current Research 2014-4, 13 p. https://doi.org/10.4095/293924

Ryan, J.J., Zagorevski, Alexandre, Williams, S.P., Roots, C.F., Ciolkiewicz, Witold, Hayward, Nathan, Chapman, J.B., 2013, Geology, Stevenson Ridge (northwest part), Yukon: Geological Survey of Canada, Canadian Geoscience Map 117, 1 sheet, scale 1:100,000.

Sicard, K.R., Naibert, T.J., Hubbard, T.D., Twelker, Evan, Wypych, Alicja, Werdon, M.B., Willingham, A.L., Gillis, R.J., Lande, L.L., and Newberry, R.J., 2017, Geologic map of the Tok River area, Tanacross A-5 and A-6 quadrangles, eastern Alaska Range, Alaska: Alaska Division of Geological \& Geophysical Surveys Preliminary Interpretive Report 2017-3, 15 p., 1 sheet, scale 1:63,360. https://doi.org/10.14509/29722

Solie, D.N., Werdon, M.B., Freeman, L.K., Newberry, R.J., Szumigala, D.J., Speeter, G.G., and Elliott, B.A., 2019, Bedrock-geologic map, Alaska Highway corridor, Tetlin Junction, Alaska to Canada border: Alaska Division of Geological \& Geophysical Surveys Preliminary In- 
terpretive Report 2019-3, 16 p., 2 sheets, scale 1:63,360. https://doi.org/10.14509/30038

Sun, Weidong, and McDonough, William, 1989, Chemical and isotopic systematics of oceanic basalts: Implications for mantle composition and processes: Geological Society of London, Special Publication 42, p. 313-345. http://dx.doi. org/10.1144/GSL.SP.1989.042.01.19

Szumigala, D.J., Newberry, R.J., Werdon, M.B., Athey, J.E., Flynn, R.L., and Clautice, K.H., 2002, Bedrock geologic map of the Eagle A-1 Quadrangle, Fortymile mining district: Alaska Division of Geological \& Geophysical Surveys Preliminary Interpretive Report 2002-1B, 1 sheet, scale 1:63,360. https://doi. org/10.14509/2864

Todd, Erin, Wypych, Alicja, and Kylander-Clark, Andrew, 2019, U-Pb and Lu-Hf isotope, age, and trace element data from zircon separates from the Tanacross D-1, and parts of D-2, C-1, and C-2 quadrangles: Alaska Division of Geological \& Geophysical Surveys Raw Data File 2019-5, 10 p. https://doi.org/10.14509/30198

Twelker, Evan, Newberry, R.J., Wypych, Alicja, Naibert, T.J., Wildland, A.D., Sicard, K.R., Regan, S.P., Athey, J.E., Wyatt, W.C., and Lopez, J.A., 2021, Bedrock geologic map of the Ladue River-Mount Fairplay area, Tanacross and Nabesna quadrangles, Alaska, in Twelker, Evan, ed., Geologic investigation of the Ladue River-Mount Fairplay area, eastern Alaska: Alaska Division of Geological \& Geophysical Surveys Report of Investigation 2021-5A. https://doi. org/10.14509/30735

Wildland, A.D., Wypych, Alicja, Regan, S.P., and Holland, Mark, 2021, U-Pb zircon ages from bedrock samples collected in the Tanacross and Nabesna quadrangles, eastern Alaska: Alaska Division of Geological \& Geophysical Surveys Preliminary Interpretive Report 2021-4, 47 p. https://doi.org/10.14509/30732

Winchester, J.A., and Floyd, P.A., 1977, Geochemical discrimination of different magma series and their differentiation products using immobile elements: Chemical Geology, v. 20, p. 325-343.

Werdon, M.B., Newberry, R.J., and Szumigala, D.J., 2001, Bedrock geologic map of the Ea- gle A-2 Quadrangle, Fortymile mining district, Alaska: Alaska Division of Geological \& Geophysical Surveys Preliminary Interpretive Report 2001-3B, 1 sheet, scale 1:63,360. https://doi. org/10.14509/2670

Wypych, Alicja, Hubbard, T.D., Naibert, T.J., Athey, J.E., Newberry, R.J., Sicard, K.R., Twelker, Evan, Werdon, M.B., Willingham, A.L., Wyatt, W.C., and Lockett, A.C., 2021, Northeast Tanacross geologic map and map units and descriptions, in Wypych, Alicja, ed., Northeast Tanacross geologic mapping project, Alaska: Alaska Division of Geological \& Geophysical Surveys Report of Investigation 2020-9B. https://doi.org/10.14509/30539

Wypych, Alicja, Naibert, T.J., Athey, J.E., Newberry, R.J., Sicard, K.R., Twelker, Evan, Werdon, M.B., Willingham, A.L., and Wyatt, W.C., 2018, Major-oxide and trace-element geochemical data from rocks collected in 2018 for the Northeast Tanacross project, Tanacross C-1, C-2, D-1, and D-2 quadrangles, Alaska: Alaska Division of Geological \& Geophysical Surveys Raw Data File 2018-4, 4 p. https://doi. org/10.14509/30113

Wypych, Alicja, Twelker, Evan, Athey, J.E., Lockett, A.C., Naibert, T.J., Sicard, K.R., Werdon, M.B., and Willingham, A.L., 2017, Major-oxide and trace-element geochemical data from rocks collected in the Tanacross C-1, D-1, and D-2 quadrangles, Alaska in 2017: Alaska Division of Geological \& Geophysical Surveys Raw Data File 2017-10, 4 p. https://doi.org/10.14509/29778

Wypych, Alicja, Twelker, Evan, Naibert, T.J., Athey, J.E., Newberry, R.J., Lopez, J.A., Regan, S.P., Sicard, K.R., Wildland, A.D., and Wyatt, W.C., 2019, Major-oxide and trace-element geochemical data from rocks collected in 2019 for the Eastern Tanacross project, Tanacross and part of Nabesna quadrangles, Alaska: Alaska Division of Geological \& Geophysical Surveys Raw Data File 2019-8, 3 p. https://doi.org/10.14509/30267

Yukon Geological Survey, 2020. Yukon Geochronology - A database of Yukon isotopic age determinations: Yukon Geological Survey. https:// data.geology.gov.yk.ca/Compilation/22 [accessed January, 1, 2021] 